\title{
nature
}

\section{University paymasters discredited}

The British government's latest policy document on higher education is a disgrace. Academics now have nothing to lose but the tenure of their jobs (itself proscribed).

THE British government's latest proposals for higher education (p.270) are most of all distinguished by their vacuity, the quality of being "content-free" in the newest civil service argot. The officials at the Department of Education and Science who have laboured for the past year and more to put flesh on the bones of Sir Keith Joseph's preconceptions about higher education and those who work therein have produced an agenda for a nondiscussion, for interested parties to say where they have always stood while the cause they are supposed to share is lost.

Shabby is the best word for this literally appalling document, and calculated indifference is the only way of describing the policy it embodies. Ordinary innocents might suppose that a state paper with ". . . higher education into the 1990s" in its title might have something valuable to say about the function of higher education in contemporary society. Carefully, the draughtsmen of this latest prospectus for British universities and polytechnics give no hostages to fortune. They simply quote the Robbins report of 1963 and launch into a discussion of the role of higher education in "the production of qualified manpower".

That calculated indifference is the British goverment's policy in higher education is now made crystal clear. (The calculation is that if the government does nothing about the problems of higher education, they will solve themselves just as mail that is left unanswered is usually overtaken by events, in this connection the disappearance of a nuisance.) Thus the green paper stolidy dodges the question that higher education has been asking the British government for at least five years, that there should be a clear definition of its function. (The explanation that there can be no longer forecast of the funds that will be available to higher education than for, say, the Ministry of Defence, is an answer to a different question.) Instead, the green paper parades the need that institutions of higher education should look to other sources than the British government to keep themselves in being. Perhaps universities and polytechnics should take the hint and make a dash for freedom). That way, they might be better off.

The plain truth is that the British government has systematically misled British higher education. Although the once-and-for-all reduction of 8.5 per cent of university budgets decreed in 1980 , together with the manipulation of the fees of overseas students whose variable effects were to reduce university incomes by an average of 5 per cent, was accompanied by promises that there would be "level funding" once the shock had been absorbed, the fact is that the budgets of the universities as a whole are still falling by between 1.5 per cent and 2 per cent a year in real terms. The polytechnics lie some two years behind on the path to penury, chiefly because of the delay in creating their supervisory National Advisory Body. During the same period, the government has put a ceiling on the numbers of students that universities and polytechnics separately are allowed to teach, has threatened a cumbersome procedure for denying academics the right to tenure of their jobs and has generally exhorted everyone in sight to find other sources of funds than the public purse.

Nobody should deny that the government has problems. In the prosperous early 1960 s, it seemed sensible that there should be a public system of higher education to which all qualified wouldbe students should have access, which principle would determine the scale of the system. It also then seemed financially feasible that the central government should meet the cost to local authorities of maintenance grants for all students winning themselves a place in higher education. Even the present government's belief that British higher education is indolently unconcerned with Britain's chronic economic difficulties is not new, as shown by the decision during the 1964 Wilson government that the polytechnics should be designated as an alternative system of higher education, one more concerned with practical affairs.

Sourly, the present government has also allowed itself to be captivated by the belief that the whole of higher education is somehow corruptly innefficient. The green paper applauds the recent Jarrett inquiry into the management of six universities but ignores the first of its recommendations, that a prerequisite of efficiency is a coherent policy framework for higher education as a whole. There may be something in the suspicion that British higher education could be operated more economically, although the most obvious diseconomies in the system now are those created by the government's own edicts of recent years. Preoccupied with these problems, the government has taken to behaving as if it wished that higher education would simply disappear. The green paper offers such perfunctory acknowledgement that the system now in being has merit that its readers may be forgiven for thinking that the government has no heart for the struggle to keep the system going.

The crunch will come quite soon. If real resources continue to decline by between 1.5 per cent and 2 per cent a year, whatever slack there is in the system will soon be exhausted. Then the grants committee and the advisory body will have to tell the government that the drain cannot continue within the present framework without striking some whole institutions off the public payroll.

Prudent institutions, universities or polytechnics, will be well advised to get out of the system before that time comes. Reorganizing for independent survival is now the game. The green paper's list of alternative sponsors should (and will) be studied carefully, but there may be others, municipal authorities for example. Only the more depressed among institutions of higher education will ask why should they bother struggling to survive when their present sponsor is so plainly not merely indifferent but ignorant of their role. Some among the others will sense that the claims upon them consist not merely of inputs and outputs ("student demand" and "qualified manpower") but of young people sharing a common conception of what the future might be like; and that knowledge is neither for its own sake nor for the winning of prestige but for a civility that the author and originators of such a banal state document could not comprehend. Groucho Marx is known not to have wanted membership of a club that would let him in. Who, in scholarship and research, dares admit to sponsorship like this?

\section{Biological manuscripts}

Miranda Robertson, Biological Sciences Editor of Nature, is now based in the Washington office of Nature. Manuscripts offered for publication may be sent, as at present, to either the London or the Washington office; with the benefit of good communications, the speed with which manuscripts are dealt will be independent of the place at which they are received. But authors are asked please in future to send four copies of manuscripts intended for publication (one for each office and two for referees). 